\title{
Through student eyes: Assessment conceptions and quality assurance
}

\author{
Serafina Pastore
}

\begin{abstract}
Recent reforms of higher education systems in Europe, since the implementation of the Bologna Process, encourage teachers to incorporate a range of assessment practices that should be more responsive to students' learning needs. Over the years, an extensive body of literature has been produced regarding principles and practice guidelines for the assessment of students' learning outcomes. However, what are students' conceptions of assessment? The present article, given the strong drive to understand the role that conceptions have in educational practices, focuses on students' conceptions of assessment within the Italian higher education system. More specifically, this paper reports on a research study realised through the administration of the Students' Conceptions of Assessment Inventory (SCoA). The data were analysed using a Confirmatory Factor Analysis (CFA) design. This study represents a useful step in understanding conceptions that students have of assessment within the framework of quality assurance. Results of the study may set the groundwork for a critical debate on changes and improvements in the higher education field.
\end{abstract}

Keywords: assessment; higher education; quality assurance; student conceptions; student learning

Received 15 April 2020; revised version received 30 June 2020; accepted 3 July 2020. Corresponding author: Serafina Pastore, University of Bari, Italy (serafina.pastore@uniba.it).

\section{Introduction}

Following the Bologna Process, from a policy-driven outcome-oriented perspective, the most recent reforms of the higher education systems worldwide embolden teachers to expand their educational paradigms by experimenting with assessment practices designed to measure students' learning outcomes (Banta \& Blaich, 2011; Eubanks, 2019; Zlatkin-Troitschanskaia, Pant, \& Coates, 2016). The global emphasis on accountability has put assessment at the core of many of the debates about quality assurance: assessment serves as a basis for effective development and continuous improvement of higher education systems (Maassen $\&$ Stensaker, 2019). Accordingly, assessment practices are required to be more responsive to students' learning needs (Carless et al., 2017). 
In Italy, the intense drive for accountability, quality assurance, and outcome-based education has also led to new interests in evaluation and assessment. The last University Reform Law (n. 240/2010) introduced a new idea of the university; instructional design, student services organisation, teaching content, and strategies have been modified in order to foster students' learning outcomes. Assessment practices serve different purposes and involve various stakeholders. In this vein, assessment practices should/could be substantially different from what they were only a few decades ago.

In order to understand these changes, it is crucial to analyse what Italian teachers and students think of assessment and if they adapt (or not) their assessment practices to new policy requirements. Aligned to this main aim, the present article focuses on students' conceptions of assessment.

The article is organised into three main sections. The first part reviews relevant literature on students' conceptions. Moreover, it illustrates the Italian higher education system and introduces the rationale and main aims of the IDEA (Improving Feedback Developing Assessment for Higher Education) project. The second part focuses on a research study, realised within the IDEA project, which aimed to explore Italian students' conceptions of assessment. More specifically, this study examined the use of the SCoA (Student Conceptions of Assessment) Brown's model in two samples of students, and this article reports its first testing in the Italian higher education context. Differences and similarities between current results and the previous studies carried out with the SCoA are also presented. Several suggestions, research implications, and practical recommendations for further improvements in the higher education field are discussed in the third part.

\section{Background}

Assessment plays a crucial role in teaching and learning processes. However, the definition of assessment represents a difficult challenge: given the radical transformations of higher education systems around the world (Broucker, De Wit, \& Verhoeven, 2018; Dorothea \& Pruisken, 2015; Pricopie et al., 2015), assessment has become a complex concept characterised by several functions and purposes.

In a scenario framed by new educational policies and practices, remarkable efforts have been made to outline (and practise) a different kind of assessment in universities. Firstly, responding to learners' needs, assessment has been linked to the active participation and collaboration of students (Carless \& Boud, 2018; Henderson, Ryan, \& Phillips, 2019; Jungblut, Vukasovic, \& Stensaker, 2015; Ryan $\&$ Henderson, 2018). Secondly, the recognition that assessment variously impacts on students' learning outcomes (Biggs \& Tang, 2011) reinforced the proposal of sustainable assessment (Boud, 2006). Assessment, in this vein, fosters learning and supports students to be, in a life-long perspective, self-regulated learners (Andrade, 2010; Sambell, McDowell, \& Montgomery, 2013). Lastly, alternative assessment 
methods (e.g., portfolio, projects, self and peer-assessment, simulation, collaborative assessment) are regarded as more effective for students to develop new competencies. These formative assessment methods and strategies support students 'to appreciate the standards that are expected from them' (Yorke, 2003, p. 480) and address the role that students have on their self-regulation; the process whereby students 'reflect on the quality of their work, judge the degree to which it reflects explicitly stated goals of criteria, and revise their work accordingly' (Andrade, 2010, p. 91).

At the same time, the strong influence exerted by outcomes-based education (Adam, 2004) and by the implementation of the Bologna Process has led to assessment that is more responsive to validity and reliability requests, and functional in terms of institutional effectiveness. Testing and measurement procedures have been reconsidered in order to determine students' learning progression, measure student learning, and provide awareness raising information to different stakeholders (faculty members, students, policy-makers, families, etc.). As a result, teachers (and students) are called to incorporate a range of different assessment practices responsive to students' learning needs, as well as aligned with the quality assurance process (Biggs \& Tang, 2011; Maki, 2017).

Over the years, extensive research literature has been produced regarding the principles and the practices for the assessment of students' learning outcomes. In the face of the lively debate and of the awareness of the implications of assessment, it becomes important to make clearer how teachers and students perceive the assessment process. The strong drive in the higher education field to analyse the role that conceptions have in assessment represents the basis for investigating the impact which assessment has on student learning. Educational research has demonstrated that conceptions represent a crucial and powerful access to the modalities (how) and purposes (why) of individuals: thus, conceptions work as a framework through which teachers and students see, analyse, and act within a specific learning context. The research literature on teachers' and students' conceptions lays out the foundation for the conceptual framework adopted for the present study. The subsequent section briefly reviews this literature.

Teachers ' and students' conceptions in the higher education context

Pratt (1992) defines conceptions as 'specific meanings attached to phenomena which then mediate our response to situations involving those phenomena' (p. 204). As abstract representations, conceptions guide our understanding of the world. Moreover, conceptions affect how we perceive and interpret a situation and how we shape our actions.

In educational research, over the years, there has been an extensive reference to conceptions as lenses through which it is possible to analyse and understand the teaching-learning process. Several studies have tried to highlight what conceptions teachers and students have about: 
- Teaching. The ways teachers think and understand teaching affect teaching practice (Gow \& Kember, 1993; Kember, 1997; Pratt, 1992; Samuelowicz \& Bain, 1992; Trigwell \& Prosser, 1997). In this perspective, teachers tend to adopt some approaches to teaching when these are consistent with beliefs about teaching. More recently, research has demonstrated that teachers' expertise influences the conceptions of and approaches to teaching (Englund, Olofsson, \& Price, 2017; Sagy, Hod, \& Kali, 2019);

- Learning. The research focus here is on the expectation of the meanings that teachers and students make of the learning process, as well as on the attempts to explain how learners view knowledge and skills development (Entwistle, 1997; Marton \& Säljö, 1976). While previous studies have highlighted the differences in learning conceptions among learners with different learning experience (Säljö, 1979), explaining how students interpret learning goals and learning situations, current studies (Vezzani, Vettori, \& Pinto, 2018) mainly indicate learning conceptions as a cluster of individuals' ideas and views about learning influenced by different aspects (e.g., gender, academic area, level of study, and educational contexts);

- Curriculum. Several aspects are encapsulated within the concept of curriculum: the knowledge and skills expected to be taught by teachers and learnt by students, as well as the value judgments on important knowledge (Cheung, 2000). The way the curriculum is perceived and understood, ranging from an instrumental perspective of content transmission to a holistic one of process and praxis (Cliff et al., 2020; Walker, 2012), influences how teaching and learning will be performed, especially during institutional reforms, renewal, and changes;

- Personal epistemology is related to the nature of knowledge, its origins, limits, and justifications. Orginally philosophers' province, personal epistemology becomes a research topic for psychologists interested in analysing individuals' conceptions of knowledge and their influence on learning (Greene, Azevedo, \& Torney-Purta, 2008). Translated into the educational context, personal epistemology conceptions are fundamental. In fact, they exert influence on teachers' instructional strategies and decisionmaking (Kember \& Gow, 1994). At the same time, personal epistemology conceptions impact students' academic performances and learning strategies (Schommer, 1993; Schraw, Bendixen, \& Dunkle, 2002; Wood \& Kardash, 2002; Yerrick, Pedersen, \& Arnason, 1998), as well as their predispositions to knowledge and their engagement with learning;

- Assessment. While teachers' conceptions of assessment are linked to their conceptions of knowledge (Postareff et al., 2012; Samuelowicz \& Bain, 1992), students' conceptions reflect students' levels of endorsement about the nature and purpose of assessment (Brown, 2004, 2008; Brown et al., 2009; Stamp, 1987; Struyven, Dochy, \& Janssens, 2005). Several studies have remarked how the focus on assessment conceptions is relevant to 
understanding how educational policies play out in practice (Brown, 2008; Brown \& Hirschfeld, 2007, 2008). Moreover, the investigations on assessment conceptions shed light on teachers' and students' practices in higher education settings (e.g., the promotion of formative assessment or the uses and misuses related to the culture of testing).

Despite the emphasis on educational research about teachers' and students' conceptions, in Italy there are very few studies focused on how students conceive and experience assessment. Even though the Italian higher education context is dealing with deep and, in some cases, radical transformations related, first of all, to the introduction of the quality assurance process, teachers' and students' assessment conceptions (and practices) seem to be mostly conventional, formal, and summative (grading, marking, selection, and certification).

Given this framework, the present paper aims to analyse what conceptions students have of assessment. This study is part of the IDEA (Improving Feedback Developing Effective Assessment for Higher Education) project: a multiple-case research project designed to effectively embed the quality assurance process and the assessment for learning perspective (Pastore et al., 2019; Pastore \& Pentassuglia, 2016). The next paragraph provides background information about the Italian higher education system and the rationale of the IDEA project.

\section{The Italian higher education system}

The assessment practices in the Italian higher education system have become more evident since 2004, as a consequence of social, policy, and economic innovations. The University Reform Law n. 240/2010 led to relevant changes in the evaluation of teaching-learning, scientific research, and administration. In a short time, renewed attention was paid to these three areas and to their main issues; therefore, evaluation and assessment have been recognised as pivotal elements for quality assurance in the higher education context.

The laws n. 240/2010 and n. 19/2012 regulate the quality assurance process in Italy. These laws aim to implement assessment more transparently and effectively, and in a way which is more useful for teachers and students, but also for policy-makers and other stakeholders (e.g., labour agencies, families, etc.). Drawing on the assessment for learning perspective and moving beyond a culture of compliance in accreditation, the university reform also led to a reconsideration of assessment aims so that students can develop skills and competencies for their future personal and professional life (Boud, 2006; Craddock \& Mathias, 2009; Gijbels et al., 2014).

While the rationale of the new assessment framework was clearly explained in the laws' statements, several problems started to arise during the reform implementation, however. First of all, the Italian teachers demonstrated a strong 
opposition to new principles and practices of assessment. Secondly, assessment malpractices (e.g., students' cheating in filling in the end-course questionnaire) became evident. Thirdly, the new and alternative assessment practices, such as those suggested by the perspective of assessment for learning, were largely unknown and unpractised.

In order to introduce and disseminate the principles and the rationale of assessment for learning within the Italian higher education, a multiple-case study research project has been designed and implemented. Moreover, this project, sponsored by the National Agency for the Assessment of Higher Education and Research (ANVUR), aimed to integrate, in a more coherent and cohesive way, the quality assurance process and the assessment of student learning.

\section{The IDEA project}

The IDEA project (Improving Feedback Developing Effective Assessment in Higher Education) aimed to implement an assessment model that, on the one hand, enhances the role of feedback for the improvement of the teaching-learning process, and, on the other hand, allows the gathering of valid and useful evidence for the quality assurance. 552 students and 30 teachers of the case university (Bari, in the South of Italy) have been involved in a set of training activities aimed to show them how to perform formative assessment and how to use assessment data in order to support both the quality assurance and the teaching-learning processes.

The IDEA project aimed to:

- Firstly, analyse teacher and student's assessment conceptions (and practices) within the Italian higher education system (Phase 1);

- Then, identify the more frequent problems that teachers and students have with feedback and detect the main characteristics of good feedback practice (Phase 2) and;

- Finally, design a model of feedback practice that could be embedded both in the teaching-learning process and in the quality assurance system (Phase 3).

Even though educational research has clearly shown how conceptions influence the teaching-learning process, it has to be noted that teachers and students' practices influence their conceptions and reflect the existing culture within an academic environment. Aligned with this perspective, during the Phase 1 of the IDEA project, the analysis of students' conceptions of assessment represented a good chance to understand what students think of and how they experience assessment and what conceptions they have about the current policy and institutional innovations. More specifically, the case-study reported below focused on this main research question:

- What do students think about the nature, the purpose, and the effects of assessment? 


\section{The Italian students' conceptions of assessment: A research study}

Generally analysed through the impact of assessment on learning outcomes, students' conceptions of assessment can be, following Brown (2008, 2011), adaptive or maladaptive. In the first case, assessment supports personal agency and student responsibility in learning. Therefore, assessment, perceived as a chance to review and improve learning, represents a legitimate process for students. In the second case, instead, assessment is rejected because it is perceived to have no validity or meaning for students. The responsibility of assessment is always external and students conceive of it as unfair or illegitimate. Brown (2008) reduced the different uses of assessment (e.g., selection, certification, monitoring, etc.) in four major conceptions of assessment. Three of these are categorised as purposes and one as anti-purpose:

- Improvement. Assessment serves to improve teaching and learning; supplying information and data, assessment allows students to judge, plan, and improve their own learning (e.g., 'Assessment is checking off my progress against achievement');

- External attributions. Assessment is functional in terms of being able to respond to accountability requirements; in this perspective, students conceive of assessment as a means to measure their future or the teaching quality (e.g., 'Assessment results predict my future performance');

- Affect/social. This dimension collects the aspects that characterise assessment as a positive experience in the learning context of the classroom. Moreover, here are included emotional and relational dimensions of assessment (e.g., 'Assessment is an engaging and enjoyable experience for me');

- Irrelevant. This dimension (the anti-purpose of assessment) reports the tendency of students to ignore or to negatively consider assessment. This aspect is evident especially when students focus on the validity of feedback on their learning (e.g., 'Assessment results are not very accurate').

These four main purposes (or dimensions) have different factors (and sub-factors) related to each other (Figure 1) that have been operationalised through a selfreported questionnaire (Brown, 2008; Brown et al., 2009): the Student Conceptions of Assessment inventory (SCoA). This questionnaire is made up of 33 statements about assessment where respondents express their agreement or disagreement on a 6-point Likert scale (Brown et al. 2009; Weekers, Brown, \& Veldkamp, 2009). 


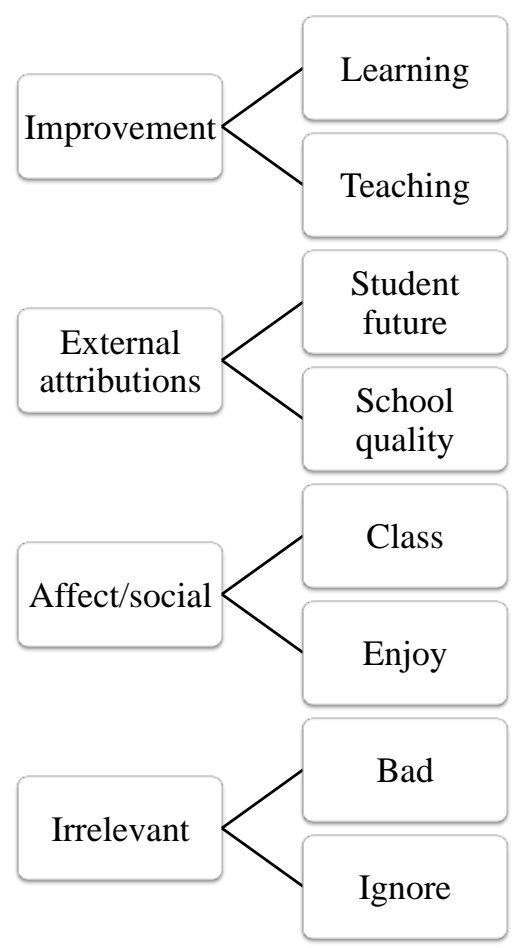

Figure 1. Student conceptions of assessment model (adapted from Brown, 2008).

For the present study, in view of the critical literature review on students' conceptions, the SCoA IV version has been used (Appendix). This inventory has been chosen because it offers a more articulated model of assessment conceptions and also because it has been used in comparative studies performed in different countries, like Hong Kong, China, Brazil, and New Zealand (Brown \& Hirschfeld, 2008; Matos, Cirino, \& Brown, 2009; McInerney, Brown, \& Liem, 2009; Wise \& Cotten, 2009). The inventory has been translated into Italian and piloted with 50 voluntary students in two Didactics modules (undergraduate degree in Education) and through a subsequent peer-review. This process ensured that the questionnaire was acceptable and understandable for the Italian students. The next section reports the research design and the main research results.

\section{Participants and main results}

Data were collected from a volunteer sample of students enrolled in graduate and post-graduate courses at the case-university. A non-probability sample design was used (a convenience sample, in the first case, and a snowball sample, in the second one). More specifically, the SCoA inventory was administered to two different samples of students: the first sample was made of 254 students involved in the IDEA research project (IDEA_sample); the second (UNIBA_sample), instead, was a casual sample (1,118 students). A total of 1,372 questionnaires were gathered. However, only 809 of them were fully filled out and were acceptable for the analysis. Even though the net response rate (59\%) was not optimal, the sample was representative of the population of interest. Given that the SCoA structure was 
established on prior empirical and theoretical grounds, a Confirmatory Factor Analysis (CFA) was performed. The objective of the analysis was to corroborate the theoretical structure of the SCoA in the Italian higher education context. For this reason, the CFA has been preferred to an Exploratory Factor Analysis (EFA) that is generally used to explore the possible underlying factor structure or constructs of a set of observed variables without a preconceived structure.

254 students involved in the IDEA research project completed the SCoA inventory. Only 216, after a data-cleaning process, were acceptable for the analysis. Students are equally distributed between male and female. The average age was 21.42 years $(\min =18, \max =40, \mathrm{sd}=4.22)$. All analyses were performed with AMOS version 20.0. The first step in the analysis was to test the theorised structure (i.e., the model) set out by Brown $(2004,2011)$ in a confirmatory factor analysis. A model, in a CFA, can be considered acceptable if the absolute fit-indices, like the Goodness-of-fit statistic (GFI), the Comparative fit index (CFI), and the Root mean square error of approximation (RMSEA) have respectively these values: GFI $>0.8$, CFI $>0.8$ and RMSEA $<0.08$ (Hooper, Coughlan, \& Mullen, 2008). Analyses showed that data scarcely fitted to the model: GFI=0.739; CFI $=0.747$; RMSEA=0,083. A backward elimination (or backward deletion) was applied: starting from the original model, one by one, all items with very poor factor loadings (or with a poor modification index) were cut. Then, one by one, those eliminated items have been included in order to verify if they could be considered again in the original model structure (Hooper et al., 2008).

At the end of the data-cleaning process, 10 items were cut. Specifically, for the Improvement conception, only one item was cut: 'I make use of the feedback I get to improve my learning'. Instead, for the External attributions, the cut item was 'Assessment provides information on how well schools are doing'. For the Affect/social conception, these two items were not included: 'Assessment motivates me and my classmates to help each other' and 'I find myself really enjoying learning when I am assessed'. However, the most relevant reduction occurred for the Irrelevant conception with a cut of 6 items: 'I ignore assessment information'; 'I ignore or throw away my assessment results'; 'Assessment has little impact on my learning'; 'Assessment interferes with my learning'; and 'Teachers are overassessing'.

The new selected model presented 23 items (Table 1) and contained the four correlated major factors, which constitute the conceptions of Improvement, External attributions, Affect/social, Irrelevant. This new factorial structure demonstrated a fairly good fit to data ( $\mathrm{GFI}=0.824, \mathrm{CFI}=0.858, \mathrm{RMSEA}=0,079)$, leading to its acceptance. 


\begin{tabular}{|c|c|c|c|c|}
\hline $\mathrm{N}$ & Conception & Factor & SCoA Wording & Factor loading \\
\hline 1 & Improvement & Learning & $\begin{array}{l}\text { I pay attention to my assessment results in order } \\
\text { to focus on what I could do better next time }\end{array}$ & 0.648 \\
\hline 5 & Improvement & Teacher & Assessment helps teachers track my progress & 0.683 \\
\hline 8 & Improvement & Teacher & $\begin{array}{l}\text { Assessment is a way to determine how much I } \\
\text { have learned from teaching }\end{array}$ & 0.796 \\
\hline 9 & Improvement & Teacher & $\begin{array}{l}\text { Assessment is checking off my progress against } \\
\text { achievement objectives and standards }\end{array}$ & 0.753 \\
\hline 15 & Improvement & Learning & $\begin{array}{l}\text { I use assessment to take responsibility for my } \\
\text { next learning steps }\end{array}$ & 0.729 \\
\hline 19 & Improvement & Learning & $\begin{array}{l}\text { I use assessment to identify what I need to } \\
\text { study next }\end{array}$ & 0.612 \\
\hline 23 & Improvement & Teacher & My teachers use assessment to help me improve & 0.741 \\
\hline 27 & Improvement & Teacher & $\begin{array}{l}\text { Teachers use my assessment results to see what } \\
\text { they need to teach me next }\end{array}$ & 0.591 \\
\hline 30 & Improvement & Teacher & $\begin{array}{l}\text { Assessment shows whether I can analyse and } \\
\text { think critically about a topic }\end{array}$ & 0.684 \\
\hline 4 & External & $\begin{array}{l}\text { Student } \\
\text { future }\end{array}$ & Assessment results show how intelligent I am & 0.529 \\
\hline 16 & External & $\begin{array}{l}\text { Student } \\
\text { future }\end{array}$ & $\begin{array}{l}\text { Assessment results predict my future } \\
\text { performance }\end{array}$ & 0.575 \\
\hline 24 & External & School & $\begin{array}{l}\text { Assessment measures the worth or quality of } \\
\text { schools }\end{array}$ & 0.633 \\
\hline 33 & External & $\begin{array}{l}\text { Student } \\
\text { future }\end{array}$ & $\begin{array}{l}\text { Assessment tells my parents how much I've } \\
\text { learnt }\end{array}$ & 0.739 \\
\hline 2 & Affect & Class & $\begin{array}{l}\text { Assessment encourages my class to work } \\
\text { together and help each other }\end{array}$ & 0.740 \\
\hline 6 & Affect & Enjoy & $\begin{array}{l}\text { Assessment is an engaging and enjoyable } \\
\text { experience for me }\end{array}$ & 0.617 \\
\hline 12 & Affect & Class & $\begin{array}{l}\text { Assessment motivates me and my classmates to } \\
\text { help each other }\end{array}$ & 0.733 \\
\hline 17 & Affect & Class & $\begin{array}{l}\text { Our class becomes more supportive when we } \\
\text { are assessed }\end{array}$ & 0.504 \\
\hline 21 & Affect & Class & $\begin{array}{l}\text { When we do assessment, there is a good } \\
\text { atmosphere in our class }\end{array}$ & 0.584 \\
\hline 25 & Affect & Class & $\begin{array}{l}\text { Assessment makes our class cooperate more } \\
\text { with each other }\end{array}$ & 0.743 \\
\hline 28 & Affect & Class & $\begin{array}{l}\text { When we are assessed, our class becomes more } \\
\text { motivated to learn }\end{array}$ & 0.526 \\
\hline 3 & Irrelevant & Bad & Assessment is unfair to students & 0.999 \\
\hline 22 & Irrelevant & Bad & Assessment results are not very accurate & 0.505 \\
\hline
\end{tabular}

Table 1. Factorial structure SCoA_IDEA sample.

The Improvement conception is made up of nine statements that focus on using assessment to support both teachers and students. Five statements form the External attribution conception; it has to be noted that only one statement is focused on the quality assurance process while the other ones are related to the Student future 
factor. Seven statements form the Affect/social conception of assessment; only one refers to the Enjoy factor demonstrating how assessment, in this new structure, is more frequently perceived in terms of social experience. The last conception, Irrelevant, has only two statements linked to students' negative opinions about the value and the accuracy of assessment.

The average of all items contributing to each factor (as displayed in Table 1) has been calculated to have the scale score. Factor inter-correlations (Table 2) showed a logically consistent pattern between Irrelevant and the three other factors (all negative): the more assessment served one of these purposes, the less it was recognized as Irrelevant. Moreover, the strongest relationship ( $r=0.76)$ was between External attribution and Improvement. Thus, students involved in the IDEA project seemed to have a twofold conception of assessment: assessment is a component of the quality assurance process; yet, it supports students to push forward their learning.

No significant gender differences were found using the t-test. Instead, a significant and negative correlation emerged between age and Improvement scale $(r=0.151)$.

\begin{tabular}{|c|c|c|c|}
\hline & Affect/social & Irrelevance & External Improvement \\
\hline \multicolumn{4}{|l|}{ Affect/social } \\
\hline Irrelevant & -0.17 & & \\
\hline External & 0.56 & -0.31 & \\
\hline Improvement & 0.47 & -0.23 & 0.76 \\
\hline
\end{tabular}

Table 2. Correlations between the main four assessment conceptions

The same procedure was applied to the second sample. 1,118 questionnaires were gathered through a snowball administration. First a data-cleaning process was required in order to identify questionnaires not acceptable for analysis. In this way, the sample was reduced to 593 students: 389 of them female and 204 male. The average age was $22.93(\min =18, \max =47, \mathrm{sd}=4.32)$.

Also in this case, the confirmatory factor analysis showed a modest fit of data to the Brown's model (GFI=0.794, $\mathrm{CFI}=0.794$, RMSEA=0,076). A backward elimination (or backward deletion) was applied: starting from the original model, one by one, all items with very poor factor loadings (or with a poor modification index) were cut. Then, one by one, those eliminated items were included in order to verify if they could be considered again in the original model structure.

In this way, 12 items were cut. Specifically, for the Improvement conception, these items were: 'I look at what I got wrong or did poorly on to guide what I should learn next' and 'Teachers use my assessment results to see what they need to teach me next'. In the External attributions dimension these items were not considered: 'Assessment results show how intelligent I am'; 'Assessment results predict my future performance'; 'Assessment is important for my future career or 
job'; 'Assessment provides information on how well schools are doing'; 'Assessment measures the worth or quality of schools'. Cutting these two items corresponds to the exclusion of the accountability factor from the original model. While the item 'When we do assessment, there is a good atmosphere in our class' was the only one eliminated from the Affect/social dimension, the items "Assessment is unfair to students"; "Assessment interferes with my learning"; "Teachers are over-assessing"; Assessment results are not very accurate" were cut from the Irrelevant dimension. Also, in this case, items with a low loading demonstrated how the model was not confirmed. The new model presented 21 items (Table 3). This factorial structure contained the four correlated major factors of the SCoA model and demonstrated a good fit to data (GFI $=0.881, \mathrm{CFI}=0.909$, RMSEA=0,069).

It is interesting to note that, in this case, the Improvement conception is made up on nine statements that focus on using assessment to support teaching and learning. The External attribution conception has only one statement and this is related to Student future: thus, in this new model, assessment is not linked to quality assurance or accountability processes. The Affect/social conception of assessment, also in this case, is related more to the Class factor demonstrating how assessment is perceived as a social process. Four statements make up the Irrelevant conception of assessment: three of them are on the Ignore factor. 


\begin{tabular}{|c|c|c|c|c|}
\hline $\mathrm{N}$ & Conception & Factor & SCoA Wording & $\begin{array}{l}\text { Factor } \\
\text { Loading }\end{array}$ \\
\hline 1 & Improvement & Learning & $\begin{array}{l}\text { I pay attention to my assessment results in order to } \\
\text { focus on what I could do better next time }\end{array}$ & 0.670 \\
\hline 5 & Improvement & Teacher & Assessment helps teachers track my progress & 0.685 \\
\hline 8 & Improvement & Teacher & $\begin{array}{l}\text { Assessment is a way to determine how much I have } \\
\text { learned from teaching }\end{array}$ & 0.890 \\
\hline 9 & Improvement & Teacher & $\begin{array}{l}\text { Assessment is checking off my progress against } \\
\text { achievement objectives and standards }\end{array}$ & 0.769 \\
\hline 10 & Improvement & Learning & $\begin{array}{l}\text { I make use of the feedback I get to improve my } \\
\text { learning }\end{array}$ & 0.517 \\
\hline 15 & Improvement & Learning & $\begin{array}{l}\text { I use assessment to take responsibility for my next } \\
\text { learning steps }\end{array}$ & 0.758 \\
\hline 19 & Improvement & Learning & $\begin{array}{l}\text { I use assessment to identify what I need to study } \\
\text { next }\end{array}$ & 0.666 \\
\hline 23 & Improvement & Teacher & My teachers use assessment to help me improve & 0.667 \\
\hline 30 & Improvement & Teacher & $\begin{array}{l}\text { Assessment shows whether I can analyse and think } \\
\text { critically about a topic }\end{array}$ & 0.715 \\
\hline 33 & External & Student future & Assessment tells my parents how much I've learnt & 0.781 \\
\hline 2 & Affect & Class & $\begin{array}{l}\text { Assessment encourages my class to work together } \\
\text { and help each other }\end{array}$ & 0.826 \\
\hline 6 & Affect & Enjoy & $\begin{array}{l}\text { Assessment is an engaging and enjoyable } \\
\text { experience for me }\end{array}$ & 0.626 \\
\hline 12 & Affect & Class & $\begin{array}{l}\text { Assessment motivates me and my classmates to } \\
\text { help each other }\end{array}$ & 0.835 \\
\hline 17 & Affect & Class & $\begin{array}{l}\text { Our class becomes more supportive when we are } \\
\text { assessed }\end{array}$ & 0.596 \\
\hline 25 & Affect & Class & $\begin{array}{l}\text { Assessment makes our class cooperate more with } \\
\text { each other }\end{array}$ & 0.813 \\
\hline 28 & Affect & Class & $\begin{array}{l}\text { When we are assessed, our class becomes more } \\
\text { motivated to learn }\end{array}$ & 0.617 \\
\hline 29 & Irrelevant & Ignore & I ignore or throw away my assessment results & 0.658 \\
\hline 31 & Affect & Enjoy & $\begin{array}{l}\text { I find myself really enjoying learning when I am } \\
\text { assessed }\end{array}$ & 0.591 \\
\hline 7 & Irrelevant & Ignore & I ignore assessment information & 0.564 \\
\hline 26 & Irrelevant & Bad & Assessment is value-less & 0.667 \\
\hline 32 & Irrelevant & Ignore & Assessment has little impact on my learning & 0.571 \\
\hline
\end{tabular}

Table 3. Factorial structure SCoA_UNIBA sample

As well as in the previous analysis, scale scores were calculated by averaging all items contributing to each factor displayed in Table 3. A logically consistent pattern between Irrelevant and the three other factors (all negative) emerged from the factor inter-correlations (Table 4): the more assessment served these purposes, the less it was irrelevant. Again, the strongest relationship ( $r=0.72$ ) was between External attribution and Improvement suggesting that students involved in this study do not see conflict between these two assessment conceptions. 


\begin{tabular}{|c|c|c|c|c|}
\hline & Affect/social & Irrelevance & External & Improvement \\
\hline \multicolumn{5}{|l|}{ Affect/social } \\
\hline Irrelevance & -0.33 & & & \\
\hline External & 0.64 & -0.43 & & \\
\hline Improvement & 0.60 & -0.31 & 0.72 & \\
\hline
\end{tabular}

Table 4. Correlations between the main four assessment conceptions

No significant gender differences were found. A significant and negative correlation was highlighted between participants' age and the Affect/social scale $(r=0.121)$.

\section{Discussion}

Participants involved in this study demonstrate how their assessment conceptions are mainly focused on the dimensions of Improvement, Affect/social, and External attributions. This is consistent with previous studies (Brown \& Hirschfled, 2008; Matos et al., 2009; Wise \& Cotten, 2009) that have shown how students tend to recognise assessment as an important element for their learning and their growth. However, the data provide evidence that students tend to associate assessment with a process of controlling/monitoring their learning.

In the new factorial structure that is partially variant with respect to the SCoA model, the items with a more relevant loading are in the Affect/social dimension and all of them gravitate around the sub-factor of the classroom. This aspect highlights how important it is for these students to support and help each other, especially when they are involved in (formal) assessment practices (e.g., exams). The conception of assessment as a control activity that teachers exert for summative purposes, rather than for the improvement of students' learning, is relevant: in this case, students' dissatisfaction with assessment and feedback practices, despite recent research perspectives (Evans, 2013; Henderson et al., 2019), remains a critical problem in the Italian higher education system.

The reduction of the Irrelevant dimension could be considered, in the case of participants in the IDEA project, as a positive result. However, in the new factorial structure, the item 'Assessment is unfair to students' is the item with the stronger loading, followed by the items 'Assessment tells my parents how much I've learnt' (External attributions) and 'Assessment is checking off my progress against achievement objectives and standards' (Improvement). Data confirm a negative representation of assessment: students who consider (and experience) assessment as a process of control seldom perceive assessment as unequal and unfair.

A little difference emerges only for students involved in the IDEA project: these students consider assessment as a strategy for the improvement of their learning. However, it could be a hazard to affirm that this result is an effect (direct 
or indirect) of the IDEA project, because the time is not sufficiently long to allow an impact evaluation of a change in students' conceptions.

The study participants demonstrate that they conceive assessment (its rationale, aims, and strategies) mainly in terms of summative assessment. Students have the intuitive idea that assessment can support them in their academic performances and learning. However, the conception of assessment as a control and selection instrument is stronger. While students, as required by the quality assurance process, are expected, and encouraged, to take an active role in creating and assessing their learning, participants in this study are not engaged and continue, passively, to perceive assessment as not embedded in their practice. Moreover, assessment is not perceived as an inclusive and equitable practice, and it is likely that this conception is related to teachers' assessment conceptions (and practices): assessment interferes with student learning only in terms of external and mandatory practices (e.g., final exams or quality assurance).

This is further evidence of the paucity and instrumental nature of assessment in Italy. The perspective of an assessment task as a chance for improving students' learning and supporting their personal growth is not recognised and practised by students (Zeng et al., 2018) involved in this research study (especially for the IDEA sample). If on the one hand, educational policy in Italy calls for innovations in the assessment domain, on the other hand, the examination-driven system seems to be predominant: thus, students have difficulties tackling assessment issues (e.g., the multiple purposes of assessment; the adequacy of assessment practice; its impact on supporting learning; and the adaptation of the institutional quality assurance framework to local contexts).

\section{Limitations}

Three main limitations can be identified in this study: Firstly, the sampling is not systematically representative and equivalent across the Italian higher education context. The oversampling from one institution limits the generalisability of the results. Hence, further, replication studies, which ensure greater variability, are required. Secondly, despite the web administration advantages (e.g., easiness in completing the questionnaire, gathering data, large availability of respondents), it is likely that the reduced control of the process and the stronger risk of respondents' automatism have impacted the quality of information gathered. Thirdly, a further study could be useful in order to verify if students involved in the IDEA project have really understood and acquired principles and practices of assessment for learning. A change in assessment conceptions and practices can be challenging: for this reason, Italian students need to be helped in these radical changes and supported with assessment literacy development paths (Carless \& Boud, 2018). 


\section{Conclusions}

Despite its intrinsic limitations, this study sheds an important light on students' conceptions of assessment: the research paths which aimed to address students' conceptions, beliefs, and values around assessment are an essential first step in order to gain valuable insights about university systems. Moreover, the exploration of students' conceptions allows a better understanding of incongruences and criticalities of the higher education systems, like the Italian one, where deep and radical transformations have been implemented.

While previous studies in the Italian context have tried to identify and describe different conceptions of assessment comparing teachers' and students' perspectives (Pastore et al., 2019; Pastore \& Pentassuglia, 2016), this study, using the SCoA inventory, has provided, with the four main assessment dimensions, a convenient reference for a critical analysis of students' reactions to institutional changes. The emphasis placed on quality assurance and the pressure on higher education institutions to have effective policies and processes led to an increased relevance of assessment in learning and teaching. However, core practices in student assessment often remain problematic.

The results of this study clearly show the persistence of the culture of testing. Assessment is a mandatory aspect in the learning process and it is always perceived in terms of external activity. Therefore, the theories and practices related to the formative assessment (e.g., an active involvement in the feedback practice) are still unknown for the Italian students. A consistent gap here emerges between theory and practice, such as between the rationale of the legislative innovation and what actors think about it and how they experience it. Ultimately, this study explores a research field that in Italy is in its infancy. Although there is a growing interest towards assessment and quality assurance, more research is needed to understand the impacts of the latest institutional innovations in this higher education system. 
Journal of Praxis in Higher Education, 2(2), 2020

\section{Author biography}

Serafina Pastore, Ph.D. on Instructional Design and Educational Assessment and Fulbright Research Fellow, works as a researcher at the University of Bari-Italy where she also teaches in graduate and post-graduate courses in Education. Her research interests include the study of assessment in higher education, formative assessment and feedback, teacher assessment literacy, and assessment of student competencies. 


\section{References}

Adam, S. (2004, July). Using learning outcomes - A consideration of the nature, role, application and implications for European education of employing earning outcomes at the local, national and international levels. Report on United Kingdom. United Kingdom Bologna Seminar. Heriot-Watt University (Edinburgh Conference Centre), Edinburgh, Scotland.

Andrade, H. L. (2010). Students as the definitive source of formative assessment: Academic self-assessment and the self-regulation of learning. In H. L. Andrade \& G. J. Cizek (Eds.), Handbook of formative assessment (pp. 90104). New York, NY: Routledge.

Banta, T. W., \& Blaich, C. F. (2011). Closing the assessment loop. Change: The Magazine of Higher Learning, 43(1), 22-27.

Biggs, J., \& Tang, K. (2011). Teaching for quality learning at university. Maidenhead: McGraw-Hill and Open University Press.

Boud, D. (2006). Sustainable assessment: Rethinking assessment for the learning society. Assessment \& Evaluation in Higher Education, 22(2), 151-167.

Broucker, B., De Wit, K., \& Verhoeven, J. C. (2018). Higher education for public value: Taking the debate beyond New Public Management. Higher Education Research \& Development, 37(2), 227-240.

Brown, G. T. L. (2004). Teachers' conceptions of assessment: Implications for policy and professional development. Assessment in Education, 11(3), 301318.

Brown, G. T. L. (2008). Conceptions of Assessment: Understanding what assessment means to teachers and students. New York: Nova Science Publishers.

Brown, G. T. L. (2011). Self-regulation of assessment beliefs and attitudes: A review of the Students' Conceptions of Assessment Inventory. Educational Psychology, 31(6), 731-748.

Brown, G. T. L., \& Hirschfeld, G. H. F. (2007). Students' conceptions of assessment and mathematics achievement: Evidence for the power of selfregulation. Australian Journal of Educational and Developmental Psychology, 7(1), 63-74.

Brown, G. T. L., \& Hirschfeld, G. H. F. (2008). Students' conceptions of assessment: Links to outcomes. Assessment in Education: Principles, Policy \& Practice, 15(1), 3-17.

Brown, G. T. L., Kennedy, K. J., Fok, P. K., Chan J. K. S., \& Yu, W. M. (2009). Assessment for student improvement: Understanding Hong Kong teachers' conception and practices of assessment. Assessment in Education: Principles, Policy \& Practice, 16(3), 347-363.

Carless, D., \& Boud, D. (2018). The development of student feedback literacy: Enabling uptake of feedback. Assessment \& Evaluation in Higher Education, 43(8), 1315-1325. 
Carless, D., Bridges, S. M., Chan, C. K. Y., \& Glofcheski, R. (Eds.) (2017). Scaling up assessment for learning in higher education. Singapore: Springer.

Cheung, D. (2000). Measuring teachers' meta-orientations to curriculum: Application of hierarchical confirmatory analysis. Journal of Experimental Education, 68(2), 149-165.

Craddock, D., \& Mathias, S. H. (2009). Assessment options in higher education. Assessment \& Evaluation in Higher Education, 34(2), 127-140.

Dorothea, J., \& Pruisken, I. (Eds.) (2015). The changing governance of higher education and research multilevel perspectives. Dordrecht: Springer.

Englund, C., Olofsson, A. D., \& Price, L. (2017). Teaching with technology in higher education: Understanding conceptual change and development in practice. Higher Education Research \& Development, 36(1), 73-87.

Entwistle, N. (1997). Contrasting perspectives on learning. In F. Marton, D., Hounsell, \& N. Entwistle (Eds.), The Experience of learning: implications for teaching and studying in higher education (pp. 3-22). Edinburgh: Scottish Academic Press.

Eubanks, D. (2019). Reassessing the elephant, part 1, Assessment Update, 31, 6-7.

Evans, C. (2013). Making sense of assessment feedback in higher education. Review of Educational Research, 83(1), 70-120.

Gijbels, D., Donche, V., Richardson, J. T. E., \& Vermunt, J. D. (2014). Learning patterns in higher education. New York, NY: Routledge.

Gow, L., \& Kember, D. (1993). Conceptions of teaching and their relationship to student learning. British Journal of Educational Psychology, 63(1), 20-33.

Greene, J. A., Azevedo, R., \& Torney-Purta, J. (2008). Modeling epistemic and ontological cognition: Philosophical perspectives and methodological directions. Educational Psychologist, 43(3), 142-160.

Henderson, M., Ryan, T., \& Phillips, M. (2019). The challenges of feedback in higher education. Assessment \& Evaluation in Higher Education, 44(8), 1237-1252.

Hooper, D., Coughlan, J., \& Mullen, M. R. (2008). Structural equation modelling: Guidelines for determining model fit. Electronic Journal of Business Research Methods, 6(1), 53-60.

Jungblut, J., Vukasovic, M., \& Stensaker, B. (2015). Student perspective on quality in higher education. European Journal of Higher Education, 5(2), 157-180.

Kember, D. (1997). A reconceptualization of the research into university academics' conceptions of teaching. Learning and Instruction, 7(3), 255275.

Kember, D., \& Gow, L. (1994). Orientations to teaching and their effect on the quality of student learning. Journal of Higher Education, 65(1), 58-74.

Maassen, P., \& Stensaker, B. (2019). From organised anarchy to de-coupled bureaucracy: The transformation of university organisation. Higher Education Quarterly, 73(4), 456-468. 
Maki, P. (2017). Real-time student assessment: Meeting the imperative for improved time to degree, closing the opportunity gap, and assuring student competencies for 21 st century needs. Sterling, VA: Stylus.

Marton, F., \& Säljö, R. (1976). On qualitative differences in learning: I. Outcome and process. British Journal of Educational Psychology, 46(1), 4-11.

Matos, D. A. S., Cirino, S. D., \& Brown, G. T. L. (2009). Students' conceptions of assessment in higher education in Brazil. In D. M. McInerney, G. T. L. Brown \& G. A. D. Liem (Eds.), Student perspectives on assessment: What students can tell us about assessment for learning (pp. 235-253). Charlotte, NC: Information Age.

McInerney, D., Brown, G. T. .L., \& Liem, G. A. D. (2009). Student perspectives on assessment. what students can tell us about assessment for learning. Charlotte, NC: Information Age.

Pastore, S., Manuti, A., Scardigno, A. F., Curci, A., \& Pentassuglia, M. (2019). Students' feedback in mid-term surveys: an explorative contribution in the Italian university context. Quality in Higher Education, 25(1), 21-37.

Pastore, S., \& Pentassuglia, M. (2016). Teachers' and students' conceptions of assessment within the Italian higher education system. Practictioner Research in Higher Education, 10(1), 109-120

Postareff, L., Virtanen, V., Katajavuori, N., \& Lindblom-Ylänne, S. (2012). Academics' conceptions of assessment and their assessment practices. Studies in Educational Evaluation, 38(3), 84-92.

Pratt, D. D. (1992). Conceptions of teaching. Adult Education Quarterly, 42(4), 203-220.

Pricopie, R., Scott, P., Salmi, J., \& Curaj, A. (Eds.) (2015). Future of higher education in Europe, volume I and II. Dordrecht: Springer.

Ryan, T., \& Henderson, M. (2018). Feeling feedback: Students' emotional responses to educator feedback. Assessment \& Evaluation in Higher Education, 43(6), 880-892.

Sagy, O., Hod, Y., \& Kali, Y. (2019). Teaching and learning cultures in higher education: A mismatch in conceptions. Higher Education Research \& Development, 38(4), 849-863.

Säljö, R. (1979). Learning about learning. Higher Education, 8(4), 443-451.

Sambell, K., McDowell, L., \& Montgomery, C. (2013). Assessment for learning in higher education. London, UK: Routledge.

Samuelowicz, K., \& Bain, J. D. (1992). Conceptions of teaching held by teachers. Higher Education, 24, 93-112.

Schommer, M. (1993). Epistemological development and academic performance among secondary students. Journal of Educational Psychology, 85(3), 406411.

Schraw, G., Bendixen, L. D., \& Dunkle, M. E. (2002). Development and validation of the epistemic belief inventory (EBI). In B. K. Hofer, \& P. R. Pintrich 
(Eds.), Personal epistemology: The psychology of beliefs about knowledge and knowing (pp. 261-275). Mahwah, NJ: Lawrence Erlbaum.

Stamp, D. (1987). Evaluation of the formation and stability of student teacher attitudes to measurement and evaluation practices. Unpublished doctoral dissertation. Macquarie University, Sydney.

Struyven, K., Dochy, F., \& Janssens, S. (2005). Students' perceptions about evaluation and assessment in higher education: A review. Assessment \& Evaluation in Higher Education, 30(4), 325-341.

Trigwell, K., \& Prosser, M. (1997). Towards an understanding of individual acts of teaching and learning. Higher Education Research and Development, 16(2), 241-252.

Vezzani, C., Vettori, G., \& Pinto, G. (2018). University students' conceptions of learning across multiple domains. European Journal of Psychology of education, 33(4), 665-684.

Walker, M. (2012). Universities and a human development ethics: A capabilities approach to curriculum. European Journal of Education, 47(3), 448-461.

Weekers, A. M., Brown, G. T. L., \& Veldkamp, B. P. (2009). Analyzing the dimensionality of the students' conceptions of assessment (SCoA) inventory. In G. T. L. Brown, D. M. McInerney, \& A. D. Liem (Eds.), Student perspectives on assessment: What students can tell us about assessment for learning (pp. 133-157). Charlotte, US: Information Age .

Wise, S. L., \& Cotten, M. R. (2009). Test-taking effort and score validity: The influence of the students' conceptions of assessment. In D. M. McInerney, G. T. L. Brown, \& A. D. Liem (Eds.), Student perspectives on assessment: What students can tell us about assessment for learning (pp. 187-205). Charlotte, NC: Information Age.

Wood, P. K., \& Kardash, C. A. (2002). Critical elements in the design and analysis of studies of epistemology. In B. K. Hofer \& P. L. Pintrich (Eds.), Personal epistemology: The psychology of beliefs about knowledge and knowing (pp. 231-260). Mahwah, NJ: Erlbaum.

Yerrick, R. K., Pedersen, J. E., \& Arnason, J. (1998). We're just spectators: A case study of science teaching, epistemology and classroom management. Science Education 82(6), 619-648.

Yorke, M. (2003). Formative assessment in higher education: Moves towards theory and the enhancement of pedagogic practice. Higher Education 45(5), 477-501.

Zeng, W., Huang, F., Yu, L., \& Chen, S. (2018). Towards a learning-oriented assessment to improve students' learning. A critical review of the literature. Educational Assessment, Evaluation and Accountability, 30(3), 211-250.

Zlatkin-Troitschanskaia, O., Pant, H. A., \& Coates, H. (2016). Assessing student learning outcomes in higher education: Challenges and international perspectives. Assessment \& Evaluation in Higher Education, 41(5), 655661. 


\section{Appendix 1. The Student Conceptions of Assessment (SCoA) inventory.}

Please, help us with some information about yourself.

Sex: $\quad$ Female $\quad$ Male

Age:

Undergraduate student Postgraduate student

IDEA project participant $\quad$ YES NO

\section{Questionnaire instructions}

Please tell us how much you agree or disagree with each statement based on YOUR OWN opinion. Fill in the box ( ) that comes closest to describing your opinion.

Note that the first column is STRONGLY DISAGREE and the last column is STRONGLY AGREE, and that the first two columns indicate disagreement, while the last four columns indicate agreement.

Thank you for participating in this survey.

\begin{tabular}{|l|l|c|c|c|c|c|c|}
\hline $\mathbf{N}$ & \multicolumn{1}{|c|}{$\begin{array}{c}\text { Conceptions of } \\
\text { Assessment }\end{array}$} & $\begin{array}{c}\text { Strongly } \\
\text { Disagree }\end{array}$ & $\begin{array}{c}\text { Mostly } \\
\text { Disagree }\end{array}$ & $\begin{array}{c}\text { Slightly } \\
\text { Agree }\end{array}$ & $\begin{array}{c}\text { Moderately } \\
\text { Agree }\end{array}$ & $\begin{array}{c}\text { Mostly } \\
\text { Agree }\end{array}$ & $\begin{array}{c}\text { Strongly } \\
\text { Agree }\end{array}$ \\
\hline 1 & $\begin{array}{l}\text { I pay attention to my } \\
\text { assessment results in } \\
\text { order to focus on } \\
\text { what I could do } \\
\text { better next time }\end{array}$ & $\square$ & $\square$ & $\square$ & $\square$ & $\square$ & $\square$ \\
\hline $\begin{array}{l}\text { Assessment } \\
\text { encourages my class } \\
\text { to work together and } \\
\text { help each other }\end{array}$ & $\square$ & $\square$ & $\square$ & $\square$ & $\square$ & $\square$ \\
\hline 3 & $\begin{array}{l}\text { Assessment is unfair } \\
\text { to students }\end{array}$ & $\square$ & $\square$ & $\square$ & $\square$ & $\square$ & $\square$ \\
\hline 4 & $\begin{array}{l}\text { Assessment results } \\
\text { show how intelligent } \\
\text { I am }\end{array}$ & $\square$ & $\square$ & $\square$ & $\square$ & $\square$ & $\square$ \\
\hline 5 & $\begin{array}{l}\text { Assessment helps } \\
\text { teachers track my } \\
\text { progress }\end{array}$ & $\square$ & $\square$ & $\square$ & $\square$ & $\square$ & $\square$ \\
\hline $\begin{array}{l}\text { Assessment is an } \\
\text { engaging and } \\
\text { enjoyable experience } \\
\text { for me }\end{array}$ & $\square$ & $\square$ & $\square$ & $\square$ & $\square$ & $\square$ \\
\hline 7 & $\begin{array}{l}\text { I ignore assessment } \\
\text { information }\end{array}$ & $\square$ & $\square$ & $\square$ & $\square$ & $\square$ & $\square$ \\
\hline & $\begin{array}{l}\text { Assessment is a way } \\
\text { to determine how } \\
\text { much I have learned } \\
\text { from teaching }\end{array}$ & $\square$ & $\square$ & $\square$ & $\square$ & $\square$ & $\square$ \\
\hline
\end{tabular}




\begin{tabular}{|c|c|c|c|c|c|c|c|}
\hline 9 & $\begin{array}{l}\text { Assessment is } \\
\text { checking off my } \\
\text { progress against } \\
\text { achievement } \\
\text { objectives and } \\
\text { standards }\end{array}$ & $\square$ & $\square$ & $\square$ & $\square$ & $\square$ & $\square$ \\
\hline 10 & $\begin{array}{l}\text { I make use of the } \\
\text { feedback I get to } \\
\text { improve my learning }\end{array}$ & $\square$ & $\square$ & $\square$ & $\square$ & $\square$ & $\square$ \\
\hline 11 & $\begin{array}{l}\text { Assessment provides } \\
\text { information on how } \\
\text { well schools are } \\
\text { doing } \\
\end{array}$ & $\square$ & $\square$ & $\square$ & $\square$ & $\square$ & $\square$ \\
\hline 12 & $\begin{array}{l}\text { Assessment } \\
\text { motivates me and my } \\
\text { classmates to help } \\
\text { each other }\end{array}$ & $\square$ & $\square$ & $\square$ & $\square$ & $\square$ & $\square$ \\
\hline 13 & $\begin{array}{l}\text { Assessment } \\
\text { interferes with my } \\
\text { learning }\end{array}$ & $\square$ & $\square$ & $\square$ & $\square$ & $\square$ & $\square$ \\
\hline 14 & $\begin{array}{l}\text { I look at what I got } \\
\text { wrong or did poorly } \\
\text { on to guide what I } \\
\text { should learn next }\end{array}$ & $\square$ & $\square$ & $\square$ & $\square$ & $\square$ & $\square$ \\
\hline 15 & $\begin{array}{l}\text { I use assessment to } \\
\text { take responsibility } \\
\text { for my next learning } \\
\text { steps }\end{array}$ & $\square$ & $\square$ & $\square$ & $\square$ & $\square$ & $\square$ \\
\hline 16 & $\begin{array}{l}\text { Assessment results } \\
\text { predict my future } \\
\text { performance }\end{array}$ & $\square$ & $\square$ & $\square$ & $\square$ & $\square$ & $\square$ \\
\hline 17 & $\begin{array}{l}\text { Our class becomes } \\
\text { more supportive } \\
\text { when we are assessed }\end{array}$ & $\square$ & $\square$ & $\square$ & $\square$ & $\square$ & $\square$ \\
\hline 18 & $\begin{array}{l}\text { Teachers are over- } \\
\text { assessing }\end{array}$ & $\square$ & $\square$ & $\square$ & $\square$ & $\square$ & $\square$ \\
\hline 19 & $\begin{array}{l}\text { I use assessment to } \\
\text { identify what I need } \\
\text { to study next }\end{array}$ & $\square$ & $\square$ & $\square$ & $\square$ & $\square$ & $\square$ \\
\hline 20 & $\begin{array}{l}\text { Assessment is } \\
\text { important for my } \\
\text { future career or job }\end{array}$ & $\square$ & $\square$ & $\square$ & $\square$ & $\square$ & $\square$ \\
\hline 21 & $\begin{array}{l}\text { When we do } \\
\text { assessment, there is a } \\
\text { good atmosphere in } \\
\text { our class }\end{array}$ & $\square$ & $\square$ & $\square$ & $\square$ & $\square$ & $\square$ \\
\hline 22 & $\begin{array}{l}\text { Assessment results } \\
\text { are not very accurate }\end{array}$ & $\square$ & $\square$ & $\square$ & $\square$ & $\square$ & $\square$ \\
\hline 23 & $\begin{array}{l}\text { My teachers use } \\
\text { assessment to help } \\
\text { me improve }\end{array}$ & $\square$ & $\square$ & $\square$ & $\square$ & $\square$ & $\square$ \\
\hline 24 & $\begin{array}{l}\text { Assessment measures } \\
\text { the worth or quality } \\
\text { of schools }\end{array}$ & $\square$ & $\square$ & $\square$ & $\square$ & $\square$ & $\square$ \\
\hline
\end{tabular}




\begin{tabular}{|l|l|c|c|c|c|c|c|}
\hline 25 & $\begin{array}{l}\text { Assessment makes } \\
\text { our class cooperate } \\
\text { more with each other }\end{array}$ & $\square$ & $\square$ & $\square$ & $\square$ & $\square$ & $\square$ \\
\hline 26 & $\begin{array}{l}\text { Assessment is value- } \\
\text { less }\end{array}$ & $\square$ & $\square$ & $\square$ & $\square$ & $\square$ & $\square$ \\
\hline $\begin{array}{l}\text { Teachers use my } \\
\text { assessment results to } \\
\text { see what they need to } \\
\text { teach me next }\end{array}$ & $\square$ & $\square$ & $\square$ & $\square$ & $\square$ & $\square$ \\
\hline 28 & $\begin{array}{l}\text { When we are } \\
\text { assessed, our class } \\
\text { becomes more } \\
\text { motivated to learn }\end{array}$ & $\square$ & $\square$ & $\square$ & $\square$ & $\square$ & $\square$ \\
\hline 29 & $\begin{array}{l}\text { I ignore or throw } \\
\text { away my assessment } \\
\text { results }\end{array}$ & $\square$ & $\square$ & $\square$ & $\square$ & $\square$ & $\square$ \\
\hline $\begin{array}{l}\text { Assessment shows } \\
\text { whether I can analyse } \\
\text { and think critically } \\
\text { about a topic }\end{array}$ & $\square$ & $\square$ & $\square$ & $\square$ & $\square$ & $\square$ \\
\hline 33 & $\begin{array}{l}\text { I find myself really } \\
\text { enjoying learning } \\
\text { when I am assessed }\end{array}$ & $\square$ & $\square$ & $\square$ & $\square$ & $\square$ & $\square$ \\
\hline $\begin{array}{l}\text { Assessment has little } \\
\text { impact on my } \\
\text { learning }\end{array}$ & $\square$ & $\square$ & $\square$ & $\square$ & $\square$ & $\square$ \\
\hline $\begin{array}{l}\text { Assessment tells my } \\
\text { Iarents how much } \\
\text { I've learnt }\end{array}$ & $\square$ & $\square$ & $\square$ & $\square$ & $\square$ & $\square$ \\
\hline
\end{tabular}

When you think of the word ASSESSMENT, which kinds or types of assessment activities come to your mind? (Fill in all that apply)

$\square$ An examination that takes one to three hours

$\square$ I score or evaluate my own performance

$\square$ My class mates score or evaluate my performance

$\square$ The teacher asks me questions out loud in class

$\square$ The teacher grades or marks or scores the written work I hand in

$\square$ The teacher grades me on a written test that he or she made up

$\square$ The teacher grades me on a written test that was written by someone other than the teacher

$\square$ The teacher observes me in class and judges my learning

- The teacher scores a portfolio of work I have done over the course of a term or school year

$\square$ The teacher scores me on an in-class written essay

$\square$ The teacher scores my performance after meeting or conferencing with me about my work

$\square$ The teacher uses a checklist to judge my in-class performance

$\square$ Something else: 